\title{
PERSPEKTIF PEREMPUAN DALAM KAJIAN IKLAN TELEVISI
}

\author{
Oleh: \\ Radita Gora ${ }^{1}$ \\ Dosen Ilmu Komunikasi Universitas Satya Negara Indonesia \\ Sandra Olifia ${ }^{2}$ \\ Dosen Ilmu Komunikasi Universitas Satya Negara Indonesia
}

\begin{abstract}
Abstrak
Iklan sering menjadikan komunikasi yang dikonstruksi dengan cara yang sangat baik (dan mungkin efektif) karena orang - orang yang menciptakan iklan telah menginvestasikan modal yang sangat banyak, waktu dan uang untuk mengetahui bagaimana pesan - pesan dipresentasikan dengan cara terbaik untuk memilih efek. Namun iklan tetap tidak lepas dari kepentingan ekonomi media yaitu menggantungkan konten sebagai bagian dari nilai jual. Seperti halnya memanfaatkan sosok perempuan pada iklan. Perempuan seringkali dimarginalisasikan sebagai posisi alat komoditas yang mampu mendatangkan keuntungan bagi iklan. Dalam hal ini aspek perempuan dalam iklan seringkali tidak bisa dilepaskan sebagai daya pikat. Sehingga dalam kajian feminis membongkar aspek ideologi ikaln melalui feminisme untuk membangun tendensi iklan dan perempuan serta bagaimana membangun citra perempuan itu sendiri melalui iklan.
\end{abstract}

\begin{abstract}
Ads often make communications constructed in a very good (and possibly effective) way because the people who created the ads have invested enormous capital, time and money to figure out how messages are presented in the best way to choose an effect. However, advertising still can not be separated from the economic interests of the media is to hang content as part of the sale value. Just like using a female figure on an ad. Women are often marginalized as positions of commodity tools that can bring benefits to advertising. In this case the aspect of women in advertising often can not be released as an allure. So in feminist studies expose aspects of ideology ikaln through feminism to build ad tendencies and women and how to build the image of women themselves through advertising.
\end{abstract}

\section{Pendahuluan}

Komunikasi biasa tetapi merupakan cara menggunakan berbagai bentuk komunikasi untuk mencapai berbagai efek. Karena berbagai bentuk komunikasi visual digunakan begitu sering dalam iklan, maka iklan pun bukan lagi menjadi pemanis dalam tayangan pertelevisian ataupun siaran radio. Melainkan iklan menjadi salah satu keutamaan dalam televisi. Dalam hal ini iklan memberikan kita miniatur dari model proses dasar komunikasi. Iklan dikodekan untuk media spesifik. Iklan menggunakan berbagai media atau saluran komunikasi yang spesifik.

Penekanan pada cerita iklan juga menciptakan pandangan - pandangan semu yang bertujuan untuk menarik perhatian audiens. Bagi produk - produk tertentu yang sudah memiliki nama atau membentuk kesadaran brand pada publik bisanya lebih leluasa untuk melakukan kreasi iklan baik secara visual ataupun konten audionya. Dalam hal ini untuk mendukung kekuatan visualisasi dan audio juga termasuk menempatkan talent untuk penggambaran sosok tokoh dalam iklan bahkan sampai mengedepankan sosok gender yang dijadikan sebagai sosok utama pada iklan. Keberadaan penggambaran gender pada iklan, di 
satu sisi bukan hanya sebatas sebagai pemanis pada iklan, melainkan juga sering dimanfaatkan untuk mengundang respon publik agar tertarik untuk melihat talent iklan sekaligus mengenalkan produk yang ditawarkan pada iklan.

Terkadang penampilan atau cerita iklan sering tidak berkaitan dengan penonjolan produk yang ditawarkan. Selain itu beragam cerita iklan yang dapat mengundang multipersepsi seringkali dinilai tidak efektif karena pesan yang disampaikan tidak memacu kesadaran (awareness) khalayak yang melihatnya bahkan ada yang menganggapnya sebagai junk (sampah).

Namun iklan di satu sisi juga dapat mengundang tanggapan positif maupun negatif dari khalayak. Ketika konstruksi pesan iklan ini kemudian menggambarkan sisi realitas yang fakta atau menyimpang, terkadang publik bisa menanggapi penggambaran cerita iklan sebagai sesuatu yang benar atau sebagai pesan yang mensugesti pikiran publik. Dalam hal ini, iklan memiliki peran yang cukup kuat dalam mempengaruhi perspektif dan persepsi publik secara mendasar. Sehingga tak jarang keberadaan iklan - iklan yang menyimpang yang menampilkan unsur kekerasan, kekotoran, pendeskritan terhadap gender maupun Suku, Agama, Ras dan Golongan (SARA) ini kemudian memberikan 'racun' perspektif yang digunakan sebagai alat provokatif kepada publik. Tak jarang iklan pun juga memanfaatkan momen tertentu sebagai alat propaganda, misalkan seperti pada persaingan kompetitor perusahaan atau produk, atau iklan pada momen politik seperti Pemilihan Umum, Pilkada atau Pilpres.

Pemosisian gender pada talent iklan seringkali menjadi kontras dengan tujuan promosi iklan itu sendiri. Bahkan tak sedikit iklan yang cenderung untuk menjadikan posisi penggambaran gender sebagai 'alat bantu dagang' yang membantu kekuatan brand produk meskipun harus menempatkan posisi talent dalam porsi yang marjinal. Diantara banyak iklan yang dapat dilihat salah satunya adalah iklan produk makanan kecil coklat Beng - beng versi 'Great Date'. Pada iklan tersebut ada asumsi mengenai terdapatnya marjinalisasi persepsi atau ada unsur memberikan persepsi sempit mengenai sosok perempuan yang ditampilkan, meskipun pada iklan tersebut menujukkan dua talent utama yang terlibat untuk mendukung story dan visualisasi iklan.

Selain itu pada contoh iklan lain seperti iklan parfum Axe juga menampilkan wanita yang berperan sebagai perempuan malaikat. Dalam hal ini perempuan tak lain halnya dijadikan sebagai alat komodifikasi (barang dagangan) pada iklan agar iklan dapat lebih menjual. Dengan memanfaatkan sosok perempuan cantik dan bertubuh seksi, tentunya produk yang di segmentasikan bagi laki - laki, diharapkan iklan dapat meraih konsumen laki - laki secara notabene karena sebelum masuk pada perilaku pembelian produk, maka perlu untuk dipersuasikan melalui iklan dengan menampilkan sosok wanita.

Keberadaan perempuan pada iklan kerap dijadikan sebagai 'penghias' untuk menarik perhatian audiens ketika melihat iklan. Penggunaan talent perempuan pada iklan ini sering menampilkan wajah - wajah baru. Lain halnya dengan iklan - iklan lama yang biasanya sering menggunakan aktor dan artis ternama untuk ditampilkan di televisi. Keberadaan wanita dalam iklan seringkali menjadi bagian ikon pada produk. Tak jarang ketika wanita ditampilkan dalam iklan, pesona ini tentunya sering dimanfaatkan untuk menjadi "daya tarik" yang mendukung penjualan produk. Sehingga posisi wanita pun ikut terlibat menjadi 'barang' komoditas yang ikut mendukung keberhasilan promosi produk.

Pada iklan biasanya 'porsi' laki - laki ditempatkan pada lingkup yang lebih luas dengan durasi yang lama. Namun pada iklan beng - beng penempatan perempuan memiliki porsi durasi yang lebih lama ditampilkan pada pria. Pada satu sisi penampilan perempuan sering tidak digambarkan sebagaimana mestinya. Konsepsi iklan sering memanfaatkan perempuansebagai daya tarik komersialnya. 
Fungsi periklanan lebih banyak dirasakan dalam dunia ekonomi kapitalis. Dalam masyarakat kapitalis, periklanan tidak dapat dihindari, penemuan dan perkembangan dunia percetakan pada abad ini, disertai juga dengan penemuan teknologi pertelevisian.(Bungin, $2008: 65)$.

Meski ada upaya dari pihak produsen untuk meningkatkan kapasitas penjualan produk melalui promosi iklan, terkadang produsen ataupun agensi iklan mencoba berpersepsi dengan adanya penampilan visualisasi iklan yang menarik akan dapat menarik pula perhatian audiens terutama pada audiens televisi. Dengan cakupan begini, pihak pengiklan ataupun pemroduksi iklan tidak memperdulikan bagaimana atau seberapa besar tingkat efektifitas iklan terhadap peningkatan brand awareness. Namun penekanan pada pesan iklan seringkali dirasa untuk dikedepankan sebagai alat utama untuk mewakili kesuksesan iklan yang dibuatnya melalui penekanan tertentu. Sehingga dalam penelitian ini, permasalahan pesan visual maupun tertulis pada iklan menjadi titik utama permasalahan yang akan diteliti mengingat pesan - pesan iklan sebagai salah satu kekuatan besar iklan dalam merekonstruksi realitas. Kekuatan makna iklan bisa bersifat tentatif, yang dimana ketika pesan disampaikan atau disebarluaskan, maka pesan pun menjadi bebas diinterpretasikan. Namun dalam hal ini bukan berarti bahwa makna pesan iklan menjadi bebas nilai.

Menurut Zoest dan Sudjiman dalam Bungin (2008 : 32), iklan televisi memiliki sifat dan kecenderungan yang mendekati pembohong, namun jarang dapat dibantah karena umumnya masuk akal. Pada iklan komersial ditandai dengan syaratnnya imajinasi dalam proses pencitraan dan pembentukan nilai - nilai estetika untuk memperkuat citra terhadap objek iklan itu sendiri. Sehingga terbentuk image, semakin tinggi estetika dan citra objek iklan, maka semakin komersial objek tersebut.

Iklan televisi bisa dikatakan memiliki penekanan pada penampilan yaitu terdiri dari dua bentuk, bentuk pertama adalah iklan yang sekedar menginformasikan produk tertentu tanpa memperhatikan penampilan iklannya, sedangkan yang kedua adalah iklan yang benar benar memperhatikan penampilannya di samping pesan atau informasi itu sendiri. Sehingga dalam hal ini, iklan televisi mencoba untuk memvariasikan pesan yang disampaikan, meskipun pada pesan - pesan tersebut terkadang tidak mudah untuk dipahami dan bersifat ambigu.

Oleh karena itu dengan pemaknaan iklan yang ambigu, tentunya mengundang interpretasi yang beragam sehingga iklan kemudian bisa menjadi multitafsir atau multipemaknaan dan bisa terjadi kesenjangan antara pembuat iklan dengan pandangan khalayak yang menonton tayangan iklan tersebut di televisi. Hampir secara keseluruhan penggunaan kata dan kalimat pada narasi iklan menggunakan pemaknaan simbolis sebagai gambaran perempuan yang ditampilkan oleh talent pada iklan. Dalam hal ini, pesan iklan merupakan perwajahan simbolis. objek iklan, maka semakin komersial objek tersebut. Kategorisasi iklan komersial dikenal sebagai bagian dari dunia industri dan ekonomi perdagangan (Bungin,2008:65).

Penempatan posisi perempuan pada penelitian iklan Beng beng tidak hanya dilihat sebagai aspek komoditas yang befungsi sebagai alat untuk memperdagangkan produk dengnan memanfaatkan sosok talent wanita, namun di satu sisi juga melihat penggambaran wanita pada iklan dan kaitannya dengan teks. Hal ini peneliti dilakukan dengan mengamati bagaimana representasi wanita yang ditampilkan pada iklan Beng beng.

Representasi pada penelitian dengan mencari makna - makna tanda pada teks yang terdapat dalam gambar (visual) maupun suara (audio) yang bisa dilihat secara implisit atau eksplisit, sadar atau tidak sadar, yang di rasakan sebagai kebenaran atau fantasi, ilmu pengetahuan atau logika umum ; dan makna - makna tersebut dibawa melalui tanda pada 
teks dan visual. Pemikiran pada penggunaan tanda merupakan hasil pengaruh dari berbagai konstruksi sosial di mana penggunaan tanda itu berada. (Kriyantono, 2005 : 264).

Pada kajian ini tentunya tidak lepas dari bentuk kajian budaya (cultural studies) yang dilihat dari aspek komunikasi dan bagaimana penggambaran representasi pada perempuan yang digambarkan melalui pesan komunikasi yang dibangun dengan iklan. Dengan melihat representasi pada teks iklan, maka disini peneliti berupaya untuk menemukan makna tanda termasuk hal - hal yang tersembunyi di balik sebuah tanda.

Sesuai dengan karakteristik iklan dari perspektif komunikasi sebagai salah satu bentuk teks dan visual, penulis akan membahas bagaimana tanda - tanda disusun di dalamnya untuk berkomunikasi dengan targetnya dan bagaimana struktur pesan tersebut merepresentasikan perempuan pada iklan. Pengkajian tentang peran perempuan pada iklan memang bisa dikatakan tidak ada habisnya. Sehingga pembahasan mengenai penggambaran perempuan dalam media massa juga tak luput dari kajian feminisme media massa. Kajian feminisme pada media massa juga melihat bagaimana bentuk pendeskritan pada wanita, wanita dijadikan sebagai 'alat komoditas' yang difungsikan untuk membangun perspektif yang mendukung dalam kesuksesan sebuah promosi produk konsumen.

Seperti halnya pada kedua iklan yang disebutkan sebelumnya, iklan Axe "versi" malaikat wanita dan Beng - beng versi "great date" memiliki pemosisian wanita yang di marginalisasikan dan dikomodifikasikan dalam cerita dan berkecenderungan memberikan gambaran citra (image) tidak seimbang, terutama dari sisi perspektifnya. Sehingga dalam hal ini pengkajian iklan dari sisi pemosisian wanita sebagai 'alat jual' yang memiliki dua sisi berbeda dari kedua iklan tersebut.

Media sebagai kekuatan kapitalis yang memanfaatkan iklan untuk menyampaikan pesan - pesan industri, selain itu juga kekuatan pesan pada media komunikasi massa juga bersifat meluas, sehingga mudah bagi media menyampaikan pesan secara cepat. Dalam hal ini, perlu dilihat bagaimana media sebagai pemegang atau pelaku kapitalis informasi menyampaikan pesan - pesan yang dinilai mendeskritkan peran wanita pada iklan terutama pada penyampaian pesan - pesan iklan melalui media elektronik televisi yang mampu menonjolkan konteks pesan dalam bentuk teks tertulis, visual dan suara.

Pada penulisan ini, penulis mengkaji permasalahan perempuan dalam media massa dengan menggunakan pendekatan Narasi. Konsep narasi telah dipetakan, dan di daya gunakan melintasi the human and social science, menurut Jane Elliot (2005) dalam Sobur (2014: xii), jejak pertempuran diskusinya sampai kini terus berkembang dalam mendefinisikan gaya naratif sebagai barang kontroversial dan pendekatan analitis.

Narasi bisa disebut fakta, bisa juga disebut berisi rekaan atau fiksi, yang direka - reka atau dikhayalkan oleh pengarangnya saja, kemudian proses bercerita yang dilihat dari alur. Seperti halnya di dalam cerita memang ada suatu fungsi besar pertukaran dan si benefisier, begiu pula lah bahwa secara homologis cerita sebagai objek merupakan suatu pertaruhan, suatu komunikasi : ada denotator (pembuat - pemberi) cerita, ada pula si penerima (destinataire) cerita. Barthes (2007) mengatakan bahwa problema yang dihadapi bukan yang berhubungan dengan usaha mengintrospeksi, memeriksa motif - motif yang ada pada si narator, bukan pula mengintrospeksi efek - efek yang dilakukan oleh narasi atau pembaca, tetapi problemanya adalah tentang bagaimana mendeskripsikan kode yang dilewati - ditaati si narrator dan si pembaca, sehingga bisa menjadi signifie - signifie di sepanjang cerita itu sendiri.

Greimas menganalogikan narasi sebagai suatu struktur makna (semantic structure). Mirip sebuah kalimat yang terdiri atas rangkaian kata - kata, setiap kata dalam kalimat menempati posisi dan fungsinya masing - masing menempati posisi dan fungsinya masing masing (sebagai subjek, objek, predikat dan seterusnya). 
Greimas melihat keterkaitan antara satu karakter dengan karakter lain. Dari fungsi fungsi karakter dalam sebuah narasi, secara sederhana bisa dibagi ke dalam tiga relasi struktur. Pertama, relasi struktural antara subjek versus objek. Relasi ini disebut juga sebagai sumbu hasrat. Objek adalah tujuan yang ingin dicapai oleh subjek. Menurut Cohan and Shires, hubungan antara subjek dan objek adalah hubungan langsung yang bisa diamati secara jelas dalam teks. Relasi subjek dan objek bisa berupa hubungan yang dikehendaki oleh kedua belah pihak atau tidak dikehendaki. Kedua, relasi antara pengirim (destinator) versus penerima (receiver). Relasi ini disebut sebagai sumbu pengiriman (axis of transmission). Ketiga, relasi structural antara pendukung versus penghambat. Relasi ini disebut sumbu kekuasaan.

Pandangan naratif juga mendukung penguatan wacana. Wacana sebagai komunikasi pikiran dengan kata - kata ; ekspresi ide - ide atau gagasan - gagasan ; konservasi atau percakapan. Berdasarkan level konseptual teoritis, wacana diartikan sebagai domain umum dari semua pernyataan, yaitu semua ujaran atau teks yang mempunyai makna dan mempunyai efek dalam dunia nyata. Sementara, dalam konteks penggunaannya, wacana berarti sekumpulan pernyataan yang dapat dikelompokkan ke dalam kategori konseptual tertentu.

\section{Pembahasan}

\subsection{Iklan Dalam Budaya Visual}

Iklan televisi merupakan salah satu dari iklan lini atas. Umumnya iklan televisi terdiri atas iklan sponsorship, iklan layanan masyarakat, iklan spot. Perkembangan iklan di Indonesia mengikuti model sejarah perkembangan iklan pada umumnya, yaitu seirama dengan perkembangan media massa. Awal masyarakat Indonesia mengenal iklan modern dari surat kabar, karena masyarakat baru mengenal surat kabar, kemudian saat masyarakat Indonesia mengenal media radio, maka lahir iklan radio, dan kemudian di saat masyarakat mengenal televisi maka lahirlah iklan televisi. Pada iklan televisi selain menawarkan tipe iklan yang instan, iklan televisi juga merupakan pertunjukan 'kecil' dalam dunia komunikasi dengan kesan - kesan yang 'besar' sebagai suatu sistem magis atau dapat merubah perilaku seseorang. Iklan televisi berbeda dengan iklan dari semua media lainnya, berdasarkan fakta bahwa konsumen dapat melihat dan mendengar aktivitas produk.(Baran, 2012 : 55).

Iklan televisi telah mengangkat medium iklan ke dalam konteks yang sangat kompleks namun jelas, berimajinasi namun kontekstual, penuh dengan fantasi tapi nyata. Sebagai point utama yang harus diketahui dari iklan televisi adalah menampilkan audio visual. Namun dari audio visual itu kemudian dapat merubah persepsi seseorang. Sehingga peran Copywriter dan Visualizer lah yang paling besar perannya dalam memberi nuansa 'hidup' kepada iklan televisi.

Pada dasarnya iklan membentuk sistem tekstual, dengan komponen - komponen dasar yang saling berkaitan untuk memposisikan produk secara positif. Namun pada saat televisi menjadi institusi kapitalis yang menjual jasa informasi, maka iklan televisi komersial adalah bagian produk dalam kategori komersial. Iklan televisi adalah sumber pendapatan utama bagi sebuah perusahaan pertelevisian. Televisi menggantungkan hidupnya untuk mengait sebanyak - banyaknya sumber dari periklanan atau acara yang dapat diiklankan. Sebaliknya, dunia periklanan melihat televisi adalah media yang paling ideal untuk penyampaian ide - ide iklan, karena televisi adalah media yang memiliki kemampuan maksimal sebagai media audiovisual yang murah dan dimiliki secara umum atau muda dijangkau oleh mayoritas masyarakat dari berbagai golongan. Dengan kata lain televis adalah media massa, yang 
merakyat dengan kemampuan publikasi yang maksimal, sehingga televisi juga disebu sebagai saluran budaya massa. (Bungin, $2008: 67$ ).

Iklan Televisi sebagai bagian dari budaya visual merujuk pada kondisi dimana visual menjadi bagian dari kehidupan sosial. Bahkan menurut Rose (2001) dalam Ida (2014 : 128), modernitas saat ini berpusat pada aspek visual. Visual enjadi hal utama pada postmodernitas. Budaya visual disini memperhatikan pada upaya gambar menampakkan (visualize) perbedaan sosial. Selain itu Rose juga menjelaskan bahwa penggambaran adalah tempat untuk mengontruksi dan menampakkan perbedaan sosial. Pada pemahaman budaya visual tidak hanya memusatkan perhatian dengan bagaimana gambar itu tampak, tetapi bagaimana gambar - gambar dilihat. Apa yang menjadi penting tentang gambar - gambar tersebut bukan gambar itu sendiri, melainkan bagaimana gambar itu dilihat oleh penonton tertentu yang melihat dengan cara tertentu pula. Sehingga penting juga terhadap citra - citra budaya media, baik dalam cara pembentukan dan penamaan citra formal mereka, maupun dalam kaitannya dengan makna dan nilai yang mereka komunikasikan.(Ida,2014 : 130)

Budaya media menghasilkan representasi yang berupaya membangkitkan persetujuan terhadap pandangan politis tertentu, membuat para anggota masyarakat melihat ideologi tertentu sebagai "hal yang sudah ditakdirkan" (bahwa terlalu banyak peran pemerintah adalah buruk, bahwa penghapusan regulasi pemerintah dan pasar bebas adalah baik, bahwa melindungi negara membutuhkan militerisasi gencar dan ketetapan hukum luar negeri yang agresif, dan seterusnya).(Kellner,2009 : 81).

\subsection{Perspektif Multikultural Kritis}

Multikultural adalah proses transaksi pengetahuan dan pengalaman yang digunakan oleh anggota masyarakat untuk menginterpretasi pandangan dunia mereka yang berbeda untuk menuju kearah kebaruan kultur. Pada kajian multikultur kita akan dihadapkan pada keragaman teks yang ditentukan dari aspek demografis dan geografis masyarakat yang memiliki pandangan dan kultur yang berbeda.

Proyek multikultural membenarkan kontribusi positif pada budaya dan masyarakat dari beragam ras, gender, dan identitas seksual, kesukuan, serta kelompok dan kelas sosial. Karya - karya dari teori feminis dan multikulturalis lebih banyak mengundang ketertarikan terutama dalam konten yang menganalisis ras, gender, kebangsaan, dan seksualitas alternatif. Dapat dikatakan bahwa Multikultural digunakan sebagai konsep umum untuk berbagai intervensi dalam studi budaya.

Dalam sebuah pendekatan multikultural yang kritis, melibatkan analisis terhadap hubungan dominasi dan penindasan, cara kerja stereotip, perlawanan bagian dari kelompok kelompok yang telah distigmatisasi terhadap representasi yang dominan, dan perjuangan kelompok - kelompok ini untuk merepresentasikan dirinya, untuk melawan representasi dominan dan terdistorsi, dan untuk menghasilkan berbagai representasi yang lebih positif.

Studi budaya media kritis juga ingin menghubungkan berbagai teorinya dengan praktik, untuk mengembangkan politik oposisional dalam budaya dan masyarakat kontemporer, dengan menyumbang bagi pengembangan hegemoni tandingan terhadap hegemoni konservatif pada tahun - tahun silam. Sudut pandang kritis melihat budaya pada dasarnya politis dan, seperti dalam banyak kasus, mendorong posisi politis tertentu, dan merupakan kekuatan - kekuatan yang ikut membantu dominasi atau perlawanan. Pandangan semacam ini menerima budaya dan masyarakat sebagai dataran yang diperebutkan, dan memilih ber aliansi dengan berbagai bentuk perlawanan dan hegemoni tandingan melawan berbagai kekuatan dominasi. Dalam penjelasan ini diterangkan bahwa studi budaya kritis berlaiansi dengan multikulturalisme yang memberontak, yang mendukung perjuangan kelompok tertindas melawan penguasaan dan perendahan, memihak mereka yang berjuang 
melawan ketidaksetaraan, ketidakadilan, dan penindasan. Multikulturalisme yang memberontak tidak hanya mendaftar perbedaan, namun juga menganalisis berbagai relasi ketidaksetaraan dan penindasan yang menimbulkan perjuangan.

Studi budaya yang kritis harus bersikeras menguji dan memeriksa berbagai metode, posisi, asumsi dan intervensinya sendiri, dan secara terus menerus mempertanyakan hal - hal itu dan merevisi serta mengembangkannya. Karena itu teori - teori budaya dan sosial yang kritis harus terbuka fleksibel, tidak dogmatis, dan tanpa jaminan. Ketika bersinggungan dengan media, konteks komunikasi melihat bagaimana media sebagai saran dogmatis namun bersikap fleksibel sebagai independensi yang berkepentingan.

\subsection{Iklan sebagai Media Kapitalis}

Memahami Iklan sebagai media kapitalis yang dimulai dengan mengajukan pertanyaan tentang apakah iklan itu? Pertanyaan ini bisa saja disebut berlebihan, namun di saat kita sadar bahwa iklan semain hari semakin banyak kita temui dalam kehidupan sehari hari, kapan pun dan dimana pun kia berada, sejak seseorang bangun tidur sampai menjelang tidur kembali.

Sebagai media informasi, iklan menempatkan diri sebagai bagian penting dalam mata rantai kegiatan ekonomi kapitalis. Karenanya iklan selalu dilihat sebagai bagian dari media kapitalis, dalam arti iklan adalah bagian tak terpisahkan dari rangkaian kegiatan perusahaan yang tak lain adalah milik kapitalis. Demikian pula kehadiran iklan semata - mata untuk menyampaikan 'pesan' kapitalis. Sehingga dapat di lihat bahwa iklan komersial hanya lahir dari konsep - konsep kapitalis, karena itu pula iklan tetap hidup dan berkembang bersama kapitalis.

Menurut para pembela industri berpendapat bahwa : (Baran, $2012: 56)$

1. Iklan mendukung sistem ekonomi kita ; tanpanya produk - produk baru tidak dapat diperkenalkan dan perkembangan - perkembangan lain tidak dapat diumumkan. Iklan produk - produk dan bisnis baru yang bersaing memberi kekuatan pada mesin ekonomi kita, mendorong pertumbuhan ekonomi, dan menciptakan lapangan pekerjaan dalam berbagai industri.

2. Iklan digunakan untuk mengumpulkan informasi sebelum membuat keputusan membeli.

3. Pendapatan iklan memungkinkan media massssa yang "gratis" tidak hanya kita gunakan sebagai sarana hiburan, tetapi juga untuk memelihara demokrasi kita.

4. Dengan menunjukkan kemurahan hati kapitalistis kepada kita, masyarakat bebas perusahaan, periklanan meningkatkan produktivitas nasional dan meningkatkan standar hidup.

Dalam sistem kapitalis, komoditas bukanlah produksi yang surplus bagi pemilik produksi tunggal. Daripada produksi ini dijual di pasar yang belum dikenal, lebih baik menjual pada seseorang untuk menjual hasil produksi mereka di pasar. Hasil penjualan produksi di pakai untuk investasi dan keperluan pribadi. Proses pembelian dan penjualan dalam system kapitalis yang demikian, berbeda dengan keadaan pasar sebenarnya. Seperti halnya kapitalisme yang sebagaimana ditekankan oleh Marx dalam Giddens (1986 : 42) adalah suatu sistem produksi komoditi. Dalam sistem kapitalis para pemroduksi tidak sekedar menghasilkan bagi keperluannya sendiri atau untuk kebutuhan individu - individu yang mempunyai kontak pribadi dengan mereka ; kapitalisme melibatkan pasar pertukaran yang mencakup nasional atau bahkan seringkali yang mencakup dunia internasional. Menurut Marx, setiap komoditi mempunyai suatu aspek 'ganda' : di satu pihak 'nilai pakai' dan dilain pihak 'nilai tukar'nya. Nilai pakai yang hanya 'direalisasikan dalam proses konsumsi' mempunyai acuan terhadap keperluan - keperluan di mana sifat - sifat suatu komoditi sebagai suatu benda fisik yang bisa digunakan untuk maksud itu 
Bentuk Iklan adalah sebagai artefak simbolis yang dibangun dari konvensi budaya tertentu. Menurut Barthes, setiap iklan adalah sebuah pesan, yaitu bahwa iklan mengandung suatu sumber yang mengeluarkannya, yaitu perusahaan yang menghasilkan produk yang diluncurkan (dan dibangga - banggakan), suatu titik resepsi - penerimaan, yaitu publiknya, dan suatu saluran transmisi, yang disebut orang sebagai support iklan itu. (Barthes, 2007 : 281).

Pengirim pesan untuk mengantisipasi respon, melihat kemungkinan audiens menggunakan pengetahuan bersama dari berbagai konvensi. Penerima pesan menggunakan tubuh yang sama dari pengetahuan budaya untuk membaca pesan, menyimpulkan niat pengirim, mengevaluasi konten, dan merumuskan tanggapan. Berbagai citra simbolis dalam periklanan semacam itu berusaha menciptakan hubungan antara produk yang ditawarkan dengan ciri - ciri yang bermakna dan diinginkan secara sosial. Untuk menghasilkan kesan bahwa jika seseorang ingin menjadi tipe orang tertentu.

Periklanan menjual produk dan pandangan dunia melalui citra, retorika, slogan dan penyejajaran dalam iklan yang menggunakan begitu banyak sumber artistic, penelitian psikologi, dan strategi pasar. Iklan - iklan ini mengungkapkan dan memperkuat citra - citra dominan tentang gender serta posisi pria dan wanita untuk menempati posisi - posisi subjek yang sangat spesifik.(Kellner, $2009: 342$ ).

Terdapat empat elemen gaya periklanan yang dapat dibedakan. Setiap gaya divariasikan oleh budaya : (Mooij, $2005:$ 139)

1. Menarik (termasuk motif dan nilai)

2. Gaya Komunikasi (eksplisit, implisit, langsung dan tidak langsung)

3. Bentuk Iklan Dasar (Testimonial, drama dan hiburan)

4.Eksekusi (Bagaimana masyarakat menyikapi)

Iklan sebagai media kapitalis tidak lepas dari tujuan pengejaran keuntungan yang merupakan hal yang hakiki dalam kapitalisme :'tujuan dari modal bukan untuk melayani kebutuhan - kebutuhan tertentu, akan tetapi untuk menghasilkan keuntungan. Bentuk keuntungan pada iklan bukan hanya sekedar purchasing atau sales promotion, melainkan memanfaatkan pesan kekuatan visual untuk mampu mempersuasi khalayak.

Oleh karena kapitalisme didasarkan atas persaingan dalam hal pengejaran keuntungan, maka peningkatan teknologi, terutama mekanisasi produksi yang semakin berkembang, merupakan senjata ampuh bagi setiap kapitalis du dalam perjuangannya untuk mempertahankan hidup di pasaran, sehingga seorang pengusaha bisa memperbesar bagian keuntungannya dengan cara berproduksi lebih murah daripada saingan saingannya.(Giddens, $1986: 65$ ).

\subsection{Representasi}

Teks dipandang sebagai sarana sekaligus media melalui mana satu kelompok menggunggulkan diri sendiri dan memarjinalkan kelompok lain. Pada titik inilah representasi penting dibicarakan. Istiah representasi itu sendiri menunjuk pada bagaimana seseorang, satu kelompok, gagasan atau pendapat tertentu ditampilkan dalam iklan media.

Stuart Hall menggaambarkan aspek representasi sebagai bagian teratas dalam sirkuit budaya yang ikut menghubungkannya dengan regulasi, identitas, konsumsi dan produksi. Sirkuit Budaya menggambarkan hubungan - hubungan atau koneksi antara representasi dengan identitas, regulasi, konsumsi dan produksi. Kesatuan ini semua berkaitan degan bagaimana makna diproduksi melalui penggambaran identitas dan peristiwa/kejadian yang berhubungan dengan konsumsi, berhubungan dengan proses produksi makna, dan pada 
akhirnya berhubungan dengan representasi yang ada di media massa, demikian sebaliknya.(Ida, 2014: 49).

Representasi adalah bagian esensial dari prosses di mana makna diproduksi dan dipertukarkan diantara anggota - anggota dari sebuah budaya. Representasi melibatkan penggunaan dari bahasa, tanda - tanda dan gambar - gambar yang mewakili atau merepresentasikan sesuatu. (Ida, 2014 : 51). Representasi menghubungkan antara makna dan bahasa terhadap budaya. Hall mengatakan bahwa representasi berarti menggunakan bahasa untuk berkata tentang sesuatu yang bermakna kepada orang lain.

Bahasa adalah media melalui mana pikiran, ide - ide, dan perasaan direpresentasikan dalam sebuah budaya. Representasi melalui bahasa menjadi sentral bagi proses - proses ketika makna diproduksi. Sistem representasi ini meliputi objek (object) orang (people), dan kejadian atau peristiwa (event) yang berhubungan dengan seperangkat konsep - konsep atau mental representations yang kita bawa dalam benak kepala kita.

Aspek bahasa pada masing - masing media massa memiliki gaya yang berbeda. Seperti bahasa iklan pada masing - masing media massa tentu memiliki gaya yang berbeda dalam menampilkan gaya bahasa. Sehingga pemaknaan dari segi bahasa iklan juga perlu dilihat dari jenis media apa yang digunakan untuk menampilkan iklan tersebut.

Hall (1997) juga mengatakan bahwa bahasa melukiskan relasi encoding dan decoding melalui metafora produksi dan konsumsi. Dalam hal ini peristiwa yang ditandakan (encode) sebagai realitas. Bagaimana peristiwa itu dikonstruksi sebagai realitas oleh wartawan / media. Realitas selalu siap ditandakan ketika kita menganggap dan mengkonstruksi peristiwa tersebut sebagai sebuah realitas. Selain itu ketika kita memandang sesuatu sebagai realitas, pertanyaan berikutnya adalah bagaimana realitas itu digambarkan. Berdasarkan keterangan diatas, kita menggunakan perangkat secara teknis. Dalam bahasa tulis, alat teknis itu adalah kata, kalimat atau proposisi, grafik, dan sebagainya. Pada hal berikutnya adalah bagaimana peristiwa tersebut diorganisir ke dalam kovensi - konvensi yang diterima secara ideologis. Bagaimana kode - kode representasi dihubungkan dan diorganisasikan ke dalam koherensi sosial seperti kelas sosial, kepercayaan dominan yang ada dalam masyarakat (Patriarki, materialisme, kapitalisme dan sebagainya).(Eriyanto,2006 : 114).

Representasi yang pada akhirnya menghubungkan antara makna dan bahasa terhadap budaya. Hall mendefinisikan bahwa representasi disini berarti menggunakan bahasa untuk berkata tentan sesuatu yang bermakna kepada orang lain. Represetasi adalah bagian esensial dari proses di mana makna diproduksi dan dipertukarkan diantara anggota - anggota dari sebuah budaya. Dalam Naraso, representasi disini melibatkan cara bercerita atau bertutur yang mewakili atau merepresentasikan sesuatu.

Banyak karya terdahulu mengenai kaum perempuan maupun budaya populer yang ditekankan pada apa yang disebut Tuchman sebagai "anihilasi perempuan secara simbolis". Hal ini merujuk pada cara produksi kultural maupun berbagai representasi / penggambaran media yang mengabaikan, dan mengesampingkan, memarjinalkan atau meremehkan kaum perempuan beserta kepentingan mereka. Kaum perempuan tidak ada, atau direpresentasikan (dan hendaknya kita ingat bahwa kepedulian budaya populer terhadap perempuan sering kali diarahkan sepenuhnya pada representasi - representasi mereka, seperti apa tampaknya mereka) dalam bentuk stereotip - stereotip yang didasarkan pada daya tarik seksual maupun kinerja domestik. Pende kata, kau perempuan "secara simbolis dianihilasikan / disirnakan" oleh media dengan cara dianggap tidak ada, dikutuk, atau diremehkan.Berbagai representasi kultural kaum perempuan di dalam media massa dianggap bekerja mendukung dan meneruskan pembagian kerja seksual yang sudah umum diterima maupun konsepsi konsepsi ortodoks feministas dan maskulinitas. (Strinati, 2016 : 223). 


\subsection{Feminisme}

Feminisme yang berasal kata dari "Femme" (woman), berarti perempuan (tunggal) yang berjuang untuk memperjuangkan hak - hak kaum perempuan (jamak) sebagai kelas sosial. Tujuan dari feminism ini adalah keseimbangan interelasi gender. Dalam arti leksikal, feminisme adalah gerakan wanita yang menuntut persamaan hak sepenuhnya antara kaum wanita dan ria. Feminisme ialah teori tentang persamaan antara laki - laki dan wanita di bidang politik, ekonomi dan sosial ; atau kegiatan terorganisasi yang memperjuangkan hak hak serta kepentingan wanita. Feminis merupakan gerakan yang dilakukan oleh kaum wanita untuk menolak segala sesuatu yang dimarginalisasikan, disubordinasikan, dan diendahkan oleh kebudayaan yang dominan. Baik dalam tataran politik, ekonomi, maupun kehidupan sosial lainnya. Dalam tradisi Barat sejak zaman Yunani dan tradisi Yahudi - Kristen sejak awal telah mengemuka pengertian - pengertian tentang "kejantanan" (kelaki - lakian) dan "Keperempuanan" yang mengonstruksi dan mempengaruhi ide - ide tentang laki - laki dan perempuan. Ide - ide ini merupakan hasil pemikiran manusia, yang dikonstruksi sejarahnya, pengalaman dan kebudayaannya. Kaum perempuan tidak terlibat dalam membentuk perkembangan filsafat dan ilmu pengetahuan, sehingga perempuan hanya menjadi bagian dari dunia yang dikonstruksi kaum laki - laki. Sejak Plato, perempuan telah diposisikan sebagai manusia kelas dua seperti dikemukakan oleh Simon De Beauvior. Berdasarkan ini, Plato kemudian memunculkan ide mengenai jiwa rasional yang menguasai dan mengatur badan yang memuat di dalamnya ide aki - laki yang mengatur perempuan. Ide bahwa laki - aki aktif sedangkan perempuan pasif, laki - laki rasional dan perempuan emosional telah dikembangkan sejak masa Yunani. Perempuan lalu disimbolkan dari sisi non rasional dari tingkah laku manusia. Karena itu berkembang pemikiran bahwa kaum perempuan tidak perlu memiliki akses ke dunia pendidikan dan cukup sebagai mesin produksi anak saja (Lubis, $2006: 81)$.

Dalam The Science Question in Feminism, mengemukakan asumsi - asumsi dasar yang saling berkaitan yang terkandung dalam ilmu pengetahuan konvensional mengenai feminis. Pertama, epistemology, metaifisk, etika, dan politik yang terdapat dalam ilmu pengetahuan bersifat androsentrik. Kedua, meskipun ilmu pengetahuan itu sesungguhnya bersifat progresif, akan tetapi ternyata banyak melayani tendensi sosial yang represif. Ketiga, struktur sosial ilmu pengetahuan dalam banyak kehadirannya penuh dengan paksaan, bukan saja secara seksis tetapi juga rasis klasik dan kultural.(Lubis, 2009 : 101).

Menurut Ollenberger \& Hellen A.Moore (1996 : 46), dalam mengembangkan teorinya, pendekatan feminis tidak menerima pendekatan positivis atau fungsionalis karena beberapa pertimbangan berikut :

1. Pendekatan positivis menekankan penemuan kebenaran universal dengan metode verifikasi.

2. Komitmennya pada obyektivitas dan netralitas peneliti.

3. Klasifikasinya yang dikotomis serta penekanannya pada prinsip kausalitas.

4. Pandangan - pandangannya yang ahistoris.

5. Tidak melihat pemakaian bahasa sebagai medium untuk menyampaikan pemikiran peikiran, konsep - konsep dan teori - teori.

Epistemologi feminis justru mempertimbangkan faktor, ras, etnis, sosial - budaya dan historis dalam mengkonstruksi epistemologinya. Janet Chavets mengemukakan beberapa unsur yang terdapat dalam teori sosiologi feminis :

1. Masalah gender sentral dalam semua teori.

2. Hubungan gender tidak dipandang sebagai masalah.

3. Hubungan gender tidak dipandang sebagai alamiah dan kekal. 
4. Kriteria teori sosiologi feminis dapat digunakan unuk menentang, meniadakan atau mengubah suatu status quo yang merugikan atau merendahkan derajat perempuan.(Ollenberger \& Helen A.Moore, $1996: 45)$.

Dalam kajian iklan, feminisme berhubungan dengan konsep kritik feminis di media massa, yaitu studi media yang mengarahkan fokus analisis kepada peran wanita pada tayangan iklan televisi. Kritik feminis pada media bukan berarti pengeritik wanita, atau kritik tentang wanita. Arti sederhana yang dikandung adalah pengeritik memandang visualisasi dengan kesadaran khusus, kesadaran bahwa ada jenis kelamin yang banyak berhubungan dengan budaya, media, dan kehidupan.

Bila kita menganalisis perkembangan gerakan feminis sejak awal, maka ditemukan adanya persamaan mendasar dalam semua gerakan feminis, yaitu : keyakinan bahwa perempuan adalah kelompok yang tidak beruntung, karena dirugikan secara sosial - politik (budaya). Ada upaya gerakan feminis untuk menjawab dan mengatasi masalah penindasan dann ketidakadilan terhadap kaum perempuan itu. Namun terdapat perbedaan ketidaksepakatan mendasar di kalangan kaum feminis tentang penyebab dan asal usul ketidaksepakatan mendasar di kalangan kaum feminis tentang penyebab dan asal - usul ketidakadilan yang disebabkan oleh konstruksi sosial (gender) itu serta bagaimana strategi untuk mengatasinya. (Lubis, 2009 : 83).

Dalam kajian feminisme pada iklan, difokuskan pada :

- Kedudukan dan peran tokoh perempuan dalam iklan.

- Ketertinggalan kaum perempuan dalam segala aspek kehidupan termasuk pendidikan dan aktivitas kemasyarakatan.

- Memperhatikan faktor audiens, bagaimana tanggapan audiens terhadap emansipasi wanita dalam iklan terutama iklan pada media televisi.

Melihat sebagai wanita berarti membaca dengan kesadaran membongkar praduga dan ideologi kekuasaan laki - laki yang andosentris atau patriarkal, yang sampai sekarang masih menguasai pembuatan iklan. Hal ini kita mengamati bagaimana aspek dominan sebagai kapitalis dalam teks. Perbedaan jenis kelamin menjadi faktor yang mempengaruhi situasi sistem komunikasi media massa. Strinati menjelaskan bahwa salah satu pernyataan paling ekstensif dari argumen bahwa media massa "secara simbolis meniadakan" perempuan dibuat oleh Tuchman. Dia (Tuchman) mengaitkan hal ini dengan gagasannya tentang Hipotesis pencerminan yang mengemukakan bahwa media massa mencerminkan nilai - nilai sosial yang dominan di dalam masyarakat. Itu semua tidak hanya terkait dengan masyarakat sebagaimana adanya, tapi juga "representasi simbolis" nya, bagaimana masyarakat memandang dirinya sendiri. Tuchman berpendapat bahwa jika sesuatu tidak direpresentasikan sescara tegas, maka implikasinya adalah "anihilasi / peniadaan simbolis".(Strinati $2016: 224)$.

Model studi feminis, etnis, Marxis, dan cultural studies mengedepankan ontologi materialis - realis, yaitu bahwa dunia nyata membuat pembedaan material, dalam pengertian ras, kelas sosial, dan gender. Bila kita menganalisis perkembangan gerakan feminis sejak awal, maka ditemukan adanya persamaan mendasar dalam semua gerakan feminis, yaitu : keyakinan bahwa perempuan adalah kelompok yang tidak beruntung, karena dirugikan secara sosial - politik (budaya). (Salim, $2006: 60$ ).

Seringkali dalam studi budaya, laki - laki dan perempuaan telah direpresentasikan oleh media selaras dengan stereotip - stereotip kultural yang berfungsi untuk mereproduksi peranan - peranan jenis kelamin secara tradisional. Kaum laki - laki biasanya ditampilkan sebagai bersifat aktif, agresif, dan atoritatif, melakukan berbagai macam peranan yang 
penting dan beragam yang seringkali menuntut profesionalisme, efisinsi, rasionalitas, maupun kekuatan yang dijalankan secara berhasil. Sebaliknya, kaum perempuan biasanya ditampilkan menjadi subordinat, bersikap pasif, submissif, dan marjinal, menjalankan sejumlah pekerjaan sekunder dan tak menarik yang terbatas pada jenis kelamin mereka, emosi mereka maupun domestikasi mereka. Dalam memotret gender ini, media massa seringkali menegaskan sifat alami peranan jenis gender maupun ketidaksetaraan gender. (Srtinati, $2016: 227$ ).

Kaitan antara studi wanita dengan berbagai gerakan wanita semakin lemah, namun diakui bahwa gerakan itu memberikan sumbangan bagi berbagai konsep sentral studi wanita. Studi wanita lahir sebagai bidang studi yang populer dan dikonstruksi di atas kesadaran bahwa wanita sebelumnya "diabaikan" (left out) dalam ilmu pengetahuan. Menurut Robinson (1993) dalam Lubis, menjelaskan bahwa wanita dan masalah perempuan tidak tampak ke permukaan (invisible), dan dianggap menyimpang atau di luar jalur keilmiahan.

\subsection{Iklan dan Perempuan}

Dalam media komunikasi, menjadi salah satu bidang utama budaya populer yang telah menarik perhatian kaum feminis adalah iklan dan representasi perempuan di dalamnya.

Budaya media populer tidak menunjukkan kaum perempuan yang sebenarnya kepada kita. Beriringan dengan ketiadaan, pengutukan, dan peremehan perempan adalah penghilangan, bias, dan distorsi di pihak media massa. Berkenaan dengan perspektif perspektif lain yang kita jumpai, pernyataan yang disampaikan adalah bahwa budaya populer menawarkan suatu khalayan, dunia khayal kepada para konsumennya, bukan dunia nyata di mana mereka ada di dalamnya.

Dyer mengemukakan bahwa dalam analisis iklan menunjukkan bahwa gender secara berkala digambarkan sesuai dengan sterotip - stereoip tradisional : perempuan ditampilkan sangat feminin, sebagai 'objek seks', sebagai ibu rumah tangga, ibu, penata rumah ; dan laki - laki dalam situasi otoritas dan dominasi atas mereka. Selain itu Dyer juga menyimpulkan bahwa perlakuan perempuan dalam iklan bermuara pada apa yang disebut oleh seorang peneliti Amerika sebagai 'anihilasi simbolis' perempuan. Dengan kata lain, iklan mencerminkan nilai - nilai sosial yang dominan ; perempuan tidak penting, kecuali di rumah, bahkan laki - laki tahu yang terbaik, sebagaimana ditunjukkan oleh suara laki - laki untuk produk - produk kaum perempuan. (Strinati, 2016 : 229).

Liz Stanley dalam Feminist Praxis, Research, Theory and Epistemology in Feminist Sociology (1992), mengemukakan bhawa riset studi perempuan mengalami perubahan mendasar dari riset sosiolog pada tahun 1980 an, dan hal ini telihat 4 aspek yang saling terkait, yaitu : (Lubis, $2006: 119$ )

1. Pergeseran sudut pandang pria ke sudut pandang perempuan.

2. Pergeseran dari metode ilmu - ilmu pengetahuan kealaman ke metode ilmu - ilmu pengetahuan sosial - budaya.

3. Dialog feminis dan wacana persahabatan ; yakni dialog yang bersahabat untuk membangkitkan nilai - nilai dan pengalaman feminis serta penelitian yang bersudut pandang bersahabat.

4. Epistemologi yang mempertimbangkan aspek lokal, sosial dan kedudukan kaum perempuan.

Penggambaran perempuan pada iklan dalam beberapa teoritisi feminis juga telah menyisihkan dan mentransformasikan sosok - sosok yang berhubungan dengan dongeng ke dalam simbol - simbol yang begitu membangkitkan ingatan tentang pelanggaran dan pemberontakan perempuan. 
Perempuan pada iklan seperti Beng beng dikisahkan sebagai perempuan yang dijemput oleh seorang pria yang kemudian diajak pergi berkencan dan di manjakan dengan beragam fasilitas termasuk pada fasilitas mobil mewah. Namun di satu sisi harapan fasilitas mobil mewah tidak seperti harapan karena hanya memanfaatkan kendaraan umum seperti taksi dengan jenis mobil lama. Pada iklan ini ada kekuatan pesan bahwa perempuan identik dengan gaya materialism dan pria adalah aspek dominan yang mendominasi keberadaan perempuan. Sementara pada iklan axe, perempuan diposisikan cerita sebagai pembawa keberkahan dan keberuntungan bagi para pria. Pesona wanita dapat membawa pria pada kebahagiaan. Hal in tentunya menjadikan posisi wanita sebagai pemberi 'pelayanan' kepada pria seperti pembawa kepuasan.

Dalam rentetan analisis penceritaan iklan diatas dengan pendekatan naratif, dapat diamati bahwa pada penceritaan iklan Beng beng perempuan dimarginalisasikan pada pandangan yang materialis dan menginginkan kehidupan yang lebih hedonis meski di satu sisi juga diceritakan sebagai wanita yang diberikan layanan oleh pria. Sementara pada iklan Axe, perempuan diposisikan sebagai pemberi pelayanan / layanan kepada pria karena pria disini adalah posisi yang ditinggikan. Dalam kedua cerita iklan ini sama - sama memposisikan wanita sebagai under (dibawah) dari watak utama laki - laki. Hal ini tentunya menjadikan posisi perempuan sebagai alat komodifikasi iklan.

Representasi pada perempuan pada visualisasi iklan seringkali menjadi rancu dengan posisi perempuan yang selalu berada dibawah. Banyak iklan yang menempatkan perempuan dengan berbagai ragam konsep. Sehingga dalam hal ini studi feminis menjadi penting dalam melakukan kritisi terhadap perspekti iklan mengenai perempuan. Hal ini juga menjadi keutamaan iklan ketika menjadikan perempuan sebagai "barang dagangan" sehingga penempatan perempuan pada iklan menjadi berimbang.

\section{Kesimpulan}

Berdasarkan dari pembahasan sebelumnya, maka dapat ditarik kesimpulan bahwa media memiliki kekuatan untuk membangun perspektif yang cukup kuat melalui pesan yang ditampilkan melalui visualisasi iklan. Pada iklan beng beng versi 'Great Date' iklan merepresentasikan perempuan sebagai posisi yang dimarjinalkan yang dimana dari kelima item yang digunakan sebagai tanda pada iklan, posisi perempuan ditempatkan sebagai sifat yang materialis. Sementara pada posisi perempuan pada iklan parfum Axe sebagai pemberi'layanan' kepada pria. Hal ini tak ubahnya sebagai hasrat pemuas kebutuhan pria sehingga perempuan menjadi tersodorkan pada kepentingan seksualitas.

Pemaknaan terhadap iklan tanpa disadari mudah untuk mempengaruhi perspektif audiensnya, sehingga dalam hal ini Iklan menunjukkan kekuatan pesan yang disampaikan melalui media massa dan dapat dilihat sebagai proses branding melalui penguatan pesan.

Apabila dilihat dari hubungan pesan disini, penyamapaian pesan masih bersifat ambigu sehingga hubungan antara promosi produk dan pesan iklan terkadang tidak sesuai dengan tujuan iklan tersebut dibuat. Hubungan antara pesan iklan dan rentetan peran talent serta konteks cerita pada iklan tidak menggambarkan hubungan yang semestinya. Beng beng sebagai produk coklat yang dalam konteks iklan sebenarnya perlu diangkat dari sisi kenikmatan atau rasa pada produk pangan, namun dalam iklan tidak ditampilkan dari sisi rasa. Sehingga produk utama itu sendiri tidak menjadi item utama, melainkan sebagai item pelengkap untuk menutup akhir pesan iklan, meskipun pada tujuan iklan sendiri adalah untuk mempromosikan produk tersebut. 


\section{DAFTAR PUSTAKA}

Baran, Stanley J. \& Dennis K.Davis. Teori Komunikasi Massa. Jakarta : Penerbit Salemba Humanika.

Barker, Chris. 2004. Cultural Studies. Yogyakarta : Kreasi Wacana.

Barthes, Roland. 2007. Petualangan Semiologi. Yogjakarta : Pustaka Pelajar

Berger, Arthur Asa. 2000. Media Analysis Technique : Teknik - teknik Analisis Media,Ed.2. Yogyakarta : Penerbitan Universitas Atmajaya Yogyakarta.

Bungin, Burhan. 2008. Konstruksi Sosial Media Massa. Jakarta: Kencana Prenada Media Group.

Denzin, Norman K. \& Yvonna S. Lincoln. 2009. Handbook of Qualitative Research. Yogyakarta : Pustaka Pelajar.

Eriyanto. 2014. Analisis Narasi. Jakarta : Kencana Prenada Media Group.

Ida, Rachmah. 2014. Kajian Media dan Studi Budaya. Jakarta: Kencana Prenada Media Group.

Kasali, Rhenald. 1992. Manajemen Periklanan : Konsep dan Aplikasinya di Indonesia. Jakarta: Pustaka Umum Grafiti.

Kriyantono, Rachmat. 2008. Riset Komunikasi. Jakarta: Kencana Prenada Media Group.

LittleJohn \& Foss. 2008. Teori Komunikasi : Theories of Human Communication Jakarta. Salemba Humanika.

Lubis, Akhyar Yusuf. 2006. Dekonstruksi Epistemologi Modern : Dari Posmodernisme, Teori Kritis, Poskolonialisme Hingga Cultural. Jakarta : Pustaka Indonesia.

Moleong. J. Lexy. 2004. Metodologi Penelitian Kualitatif . Bandung: PT. Remaja Rosdakarya.

Piliang, Yasraf Amir. 2004. Hipersemiotika : Tafsir Cultural atas Matinya Makna. Yogyakarta : Jalasutra.

Putrayasa, Ida Bagus. 2000. Analisis Kalimat. Bandung Penerbit : Relika Aditama.

Sobur, Alex. 2006. Analisis Teks Media : Suatu pengantar untuk Analisis Wacana, Analisis Semiotika dan Analisis Framing. Bandung PT. Remaja Rosdakarya.

Sobur, Alex. 2014. Komunikasi Naratif : Paradigma, Analisis, dan Aplikasi. Bandung PT. Remaja Rosdakarya. 2003. Semiotika Komunikasi. Bandung: PT. Remaja Rosdakarya.

Strinati, Dominic. 2016. Popular Culture (Budaya Populer) : Pengantar Menuju Budaya Populer. Jakarta : Narasi.

Rusadi, Udi. 2015. Kajian Media : Isu Ideologis dalam Perspektif, Teori dan Metode. Jakarta : Rajawali Press. 